\title{
Pogrebna gostija na nagrobni steli Julije Jukunde iz Črnomlja
}

\author{
Katarina Šmid \\ UP FHŠ, Oddelek za arheologijo in dediščino ter Inštitut za arheologijo in dediščino \\ katarina.smid@fhs.upr.si
}

\section{Uvod}

Pričujoči prispevek je v prvi vrsti posvečen nekoliko nenavadni upodobitvi pogrebne gostije (cena funebris, nem. Totenmahl, angl. funerary banquet) na nagrobni steli Julije Jukunde iz Črnomlja, na kateri se med služabniki pojavi figura, ki tja ne sodi - bodisi genij letnih časov bodisi satir. Motiv je sicer glede na okoliški teritorij zgoščen prav tam, saj ga v mestnih območjih Nevioduna oziroma Siscije, pod katerih ager naj bi naselbina spadala v rimski dobi, srečamo le izjemoma. Svojevit problem predstavlja tudi datacija stele, saj je bila ta razpeta vse od konca 1. do začetka 3. stoletja, pri natančnejši opredelitvi pa poleg oprave in pričeske upodobljencev še najbolj pride $\mathrm{v}$ poštev prav zagonetni lik ob gostiji.

V provinci Panoniji so bile v rimski dobi upodobitve pogrebne gostije nadvse priljubljene. Njihov izvor še zmeraj ni enoznačno pojasnjen, kakor tudi ne simbolni pomen. Še največkrat se izpostavlja razvoj iz obredne pojedine ob pogrebu in spominskih obredjih (npr. Parentalia, Rosalia), ko so svojci umrlim ob praznikih na grobove prinašali jedačo in pijačo, upodobitev pa bi tako posredno lahko odsevala pokojnikove obede v onostranstvu (Diez 1959-1961, 47; Diez [1960] 2011, 71; Kastelic 1998, 433) oziroma aludirala na njegovo lagodno življenje po smrti in na zakonske vezi, ki so močnejše od smrti, saj nemalokrat ob mizi leži zakonski par (Stewart 2009, 255). Ena podoba naj bi tako kazala na uživanje $\mathrm{v}$ tostranstvu, ki se bo nadaljevalo $\mathrm{v}$ onostranstvo, pogrebno obredje in heroizacijo pokojnih (Dunbabin 2003, 
108-40). Likovno bržkone izvira iz reliefov grške klasične dobe, kjer so bile gostije pokojnikov upodobljene na posvetitvenih reliefih ob grobovih herojev (heroa), večji razmah pa so doživele v helenizmu, posebej v Mali Aziji in na Egejskih otokih (Conrad 2004, 57; Ciongradi 2007, 117; Stewart 2009, 255).

$\mathrm{V}$ rimski dobi je bil motiv v nagrobni umetnosti razprostranjen domala po vseh provincah, vse od sredine prvega stoletja dalje pa do pozne antike (Noelke 2005, 155-56, op. 1). Še največ ga je bilo na območjih, ki so bila zavoljo svoje lege pod neposrednim vplivom grške umetnosti, kakor so denimo obale Črnega morja, medtem ko ga je npr. na nagrobne spomenike Porenja zaneslo vojaštvo (Noelke 200o, 61; Stewart 2009, 255). Med seboj se upodobitve razlikujejo v številnih podrobnostih glede na geografsko lego, največkrat prikazana različica prikazuje moškega ali žensko oziroma večinoma zakonski par, ki se domala v vseh primerih lahko identificira s pokojnikoma. Upodobljena sta v polležečem položaju na postelji (kline). Pred njima je v sprednjem planu trinožna miza (mensa tripes), na katero sužnji nosijo hrano in posodje za vino. Portretiranec navadno drži čašo, redkeje robec (Dunbabin 2003, 104-10; Stewart 2009, 253-55).

Eno izmed večjih žarišč te tematike je bilo tudi v Panoniji, še posebej veliko primerkov je bilo odkritih v spodnjepanonskem Akvinku (Burger 1959, 37; Diez 1959-1961, 47-48). Za to provinco specifičen prizor je običajno zajet v okrajšani obliki (prim. Schober 1923, 203; Diez 1959-1961; Barkóczi 1983-1983, 123-32; Kastelic 1998, 433; Lovenjak 1998, 305). Najopaznejša razlika $\mathrm{v}$ primerjavi $\mathrm{z}$ največkrat razširjeno različico je, da postelja s pokojnikom ni prisotna in je motiv zreduciran na trinožno mizo, ki jo obdajajo služabniki. Upodobitev gostije z ležečim pokojnikom nastopa v Panoniji le redko, jo pa najdemo jugovzhodno od nje: v Trakiji, Grčiji ter Mali Aziji (Barkóczi 1982-1983, 123, 145).

$\mathrm{Na}$ reliefni površini je upodobitev največkrat locirana v ožji pas med osrednjim likovnim poljem in napisom (Dunbabin 2003, 108; Ciongradi 2007, 117; Stewart 2009, 255). Ob veliki mensa tripes na sredini stoji na levi mladenka s kozarcem, neko škatlico ter žrtvenim prtom (mappa), na desni strani pa je mladenič, ki nosi čašo ali kakšno drugo obredno posodje. Bistveno redkeje stoji za služabnikoma še po en lik (npr. Lupa n. d., $694,3792,3874)$. Na mizi so običajno razne posode, hlebci kruha ali sadje. Trinožna miza je upodobljena predimenzonirano, tako da sega skoraj do zgornjega roba polja, služabniki ob njej pa so premajhni (Diez 1959-1961, 47; Diez [1960] 2011, 71). V sosednji provinci Norik z nekaj redkimi izjemami, kakor sta denimo prizora v Šempetru (Lupa n. d., 4126) in Flaviji Solvi 
(Lupa n. d., 1179), tega prizora ni zaslediti (Schober 1923, 203; Diez 19591961, 48-49; Šašel Kos 1997, 403).

1. Nagrobna stela Julije Jukunde

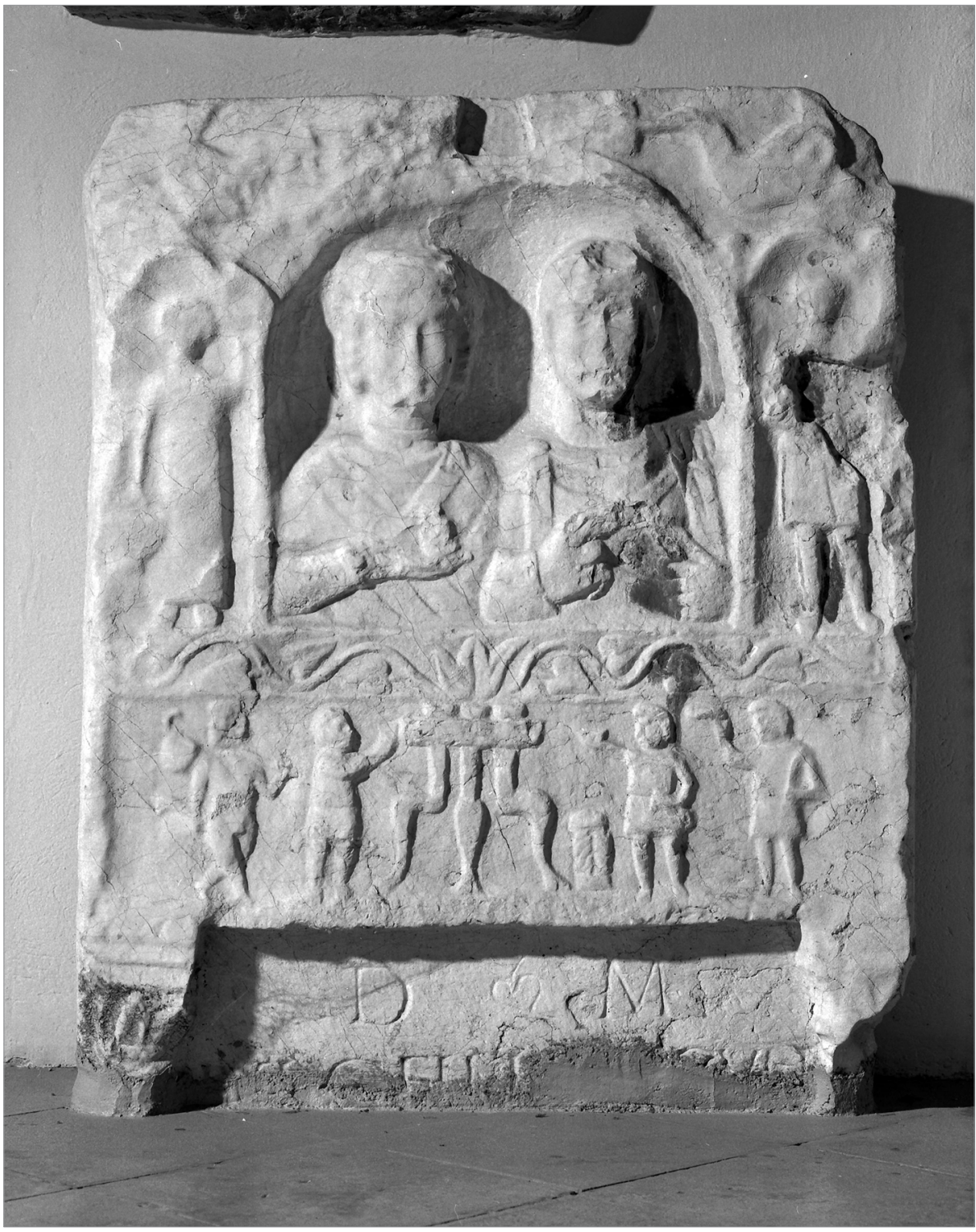

Slika I: Nagrobna stela Julije Jukunde, Narodni muzej Slovenije, inv. št. L I19, foto: Tomaž Lauko 
Od siceršnjih panonskih upodobitev pogrebne gostije nekoliko odstopa prizor na nagrobni steli neke Julije (120 x 98,5 x $30 \mathrm{~cm}$; Narodni muzej Slovenije, inv. št. L 119; slika 1), na kateri je motiv umeščen v pas med osrednjim poljem in epitafom (Hoffiller in Saria 1938, 221-22, št. 487; Šašel Kos 1997, 401-3, št. 142; Lovenjak 1998, 303-5, št. 158). Stela je iz lokalnega apnenca, najdena pa je bila v Črnomlju, v Flekovem mlinu ob Lahinji leta 1906, kamor naj bi domnevno prišla iz rimske nekropole v Loki pri Črnomlju (prim. Lovenjak 1998, 303, št. 158; Lovenjak 2008, 77). Od tod izvira tudi večina rimskodobnih najdb, ta najpomembnejša rimska naselbina $\mathrm{v}$ regiji pa je bržkone imela status vikusa (Šašel 1985, 326, 332; Lovenjak 1998, 283). Za Črnomelj in z njim celo Belo Krajino zaradi pomanjkanja neizpodbitnih epigrafskih dokazov sicer ni moč z gotovostjo trditi, pod kateri ager sta spadala; bodisi pod bližje ležeči Neviodun bodisi pod bolj oddaljeno Siscijo (Lovenjak 1998, 281; Migotti 2018, 139-40).

Od nagrobnega spomenika se je ohranil le zgornji del, večji del napisnega polja je žal odlomljen. Napisno polje obdajata polstebra s kapitelom, ki spominja na korintskega, od epitafa pa sta se ohranili le zgornji dve vrstici, ki izdajata, da je nagrobni spomenik bil postavljen božanskim Manom pokojne Gajeve hčerke Julije Jukunde:

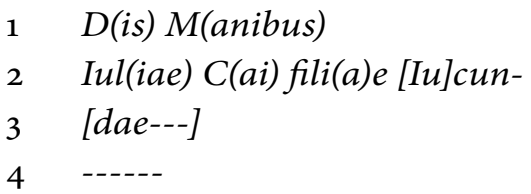

V osrednjem polju sta v polkrožno nišo postavljeni busti Julije in njenega soproga. Pokojnica na levi v desnici drži nek okrogel predmet, morda jabolko, drugo roko pa polaga na soprogovo levo ramo. Oblečena je v tuniko in plašč (palla), vrat ji krasi ogrlica z okroglim obeskom. Na glavi nosi lokalno pokrivalo. Zaradi poškodovanosti stele ga je težko natančneje opredeliti, bržkone še najbolj ustreza severnopanonskemu tipu $\mathrm{H} 7$, ki je bilo eno običajnejših pokrival rimske dobe v provinci, nagrobni spomeniki s tem tipom pa so bili razprostranjeni tako po Panoniji kot sosednjem Noriku, moč pa jih je najti tudi v Reciji in Galiji. Njihova uporaba ni ome-

$1 \quad$ Napis je transkribiran po Šašel Kos 1997, 401-3, št. 142. Saria je menil, da za dopolnitev s Secundae ali Fecundae oddeljeni prostor ne zadošča (Saria 1933, 19-20, št. 18; Hoffiller in Saria 1938, 222, št. 487), Lovenjak pa nasprotno opozori, da je možno tudi drugačno branje kognomena in predlaga Facundus, Fecundus ali Secundus (prim. Lovenjak 1998, 305; 2008, 83). 
jena na določeno obdobje; najzgodnejši znani primerek izvira iz 1. stoletja, navzgor pa so omejeni s seversko dobo (Rothe 2012, 209).

Njen soprog nosi tuniko in sagum, spet na desnem ramenu s fibulo. $\mathrm{V}$ roki drži nek močno poškodovan predmet, morda zvitek. Zaznamujejo ga na koncih privihani brki in komajda razvidna kratka brada. Ob osrednji niši se na vsaki strani nahaja še ožja niša, znotraj katere pod noriško-panonsko voluto stojita dekle v dolgem oblačilu s košarico in ogledalom (levo) oziroma mladenič v tuniki (desno). Zaradi poškodovanosti površine ni mogoče presoditi, kaj nosi v rokah. Nad lokoma sta $\mathrm{v}$ zaklinkih navzven obrnjena delfina.

Sagum, ki ga nosi pokojnik, je bil v najširši uporabi od cesarja Karakale (211-217) dalje, ko je postal obvezni del vojaške uniforme (Pochmarski 1996, 129; Rothe 2012, 159-60, op. 199; Migotti 2013, 262; Ubl 2013, 308). Čeprav sprva nedvomno vojaško oblačilo, ga je pričelo nositi tudi civilno prebivalstvo, četudi vsaj v Panoniji ne šele po Karakalinih reformah, kot se je zmotno domnevalo (Rothe 2012, 160-63; Handy in Pochmarski 2016, 12428). Poenostavljeno se je za mesta, v katerih je prebival civilni živelj, predpostavljalo, da je upodobljenec $\mathrm{v}$ sagumu civilist, medtem ko se je v mestih $\mathrm{z}$ nastanjenim vojaštvom domnevalo ravno obratno, da ga nosi pripadnik vojske - premisa, ki pa ne drži nujno (Migotti 2013, 259-60).

Pod osrednjim poljem sledi najprej rastlinski friz s srčasto oblikovanimi listi in stiliziranim listom, ki se vzpenja tik nad sredino trinožne mize in jo $s$ tem dodatno poudarja. Spodaj sledi prizor pogrebne gostije (slika 2). Trinožna miza je pomaknjena rahlo v levo, na njej pa se nahajajo trije hlebci kruha. Na desni strani ob njej stoji visoka košara, za katero sta dva služabnika, oblečena $\mathrm{v}$ za panonski prostor običajno opravo služabnikov - tuniko z dolgimi, ozkimi rokavi (tunica manicata), značilno za staroselce (cf. Rothe 2012, 149-50). V dvignjenih desnicah nosita obredno posodje, spuščena leva roka pa počiva ob telesu. Levi lik z njo drži nek podolgovat predmet, rog (?), desni pa žrtveni prt (mappa). Zagonetnejša je leva stran mize, ob kateri za služabnikom $v$ isti opravi in s čašo $v$ desnici $z$ desno nogo pred levo stopa proti mizi gol moški lik. V dvignjeni levici stiska za konec pastirske palice (pedum), na katere zavitem koncu je obešena košara ali morda culica (?). V drugi roki drži nek ukrivljen predmet, morda srp ali pa nož za obrezovanje trte (?). 


\section{Upodobitve pogrebne gostije $\mathrm{v}$ širšem mestnem območju}

Zanimivo je, da je bilo prav v Črnomlju z bližnjo okolico zgoščeno najdenih več upodobitev prizorov pogrebne gostije, poleg te so namreč znane še tri stele (cf. Lovenjak 1998, 307-11, 321-22, št. 160-61, 168). Na dveh je upodobitev drugače koncipirana, že na prvi pogled pa na Julijino stelo po razdelitvi površine in ikonografiji na moč spominja anepigrafska stela $\mathrm{z}$ zakoncema, danes hranjena v Narodnem muzeju Slovenije (inv. št. L 98; slika 3), ki bržkone tudi izvira iz iste nekropole (Hoffiller in Saria 1938, 222, št. 488; Šašel Kos 1997, 412-13, št. 148; Lovenjak 1998, 321-22, št. 168). Primerljive so tudi mere (102 x $100 \times 42 \mathrm{~cm})$, pri čemer je seveda potrebno vzeti v ozir, da se spodnji del pri obeh stelah ni ohranil. Ikonografsko se razlikujeta le $\mathrm{v}$ portretnih značilnostih zakoncev, tako da je povsem mogoče, da sta bili izdelani v isti delavnici (Hoffiller in Saria 1938, 222, št. 488; Šašel Kos 1997, 412-13, št. 148; Lovenjak 1998, 322, št. 168), čeprav zlasti Julijin portret in obdelava njene pričeske jasno kažeta, da prva stela izžareva višjo stopnje kvalitete. Hipotetično bi bila delavnica lahko locirana prav v antični naselbini v Črnomlju (Lovenjak 2008, 95). Na žalost se je figura za levim služabnikom v prizoru pogrebne gostije ohranila le v obrisih in je nemogoče presoditi, ali gre za isti lik; sodeč po siceršnjih ujemanjih bi bilo to sicer zelo možno.

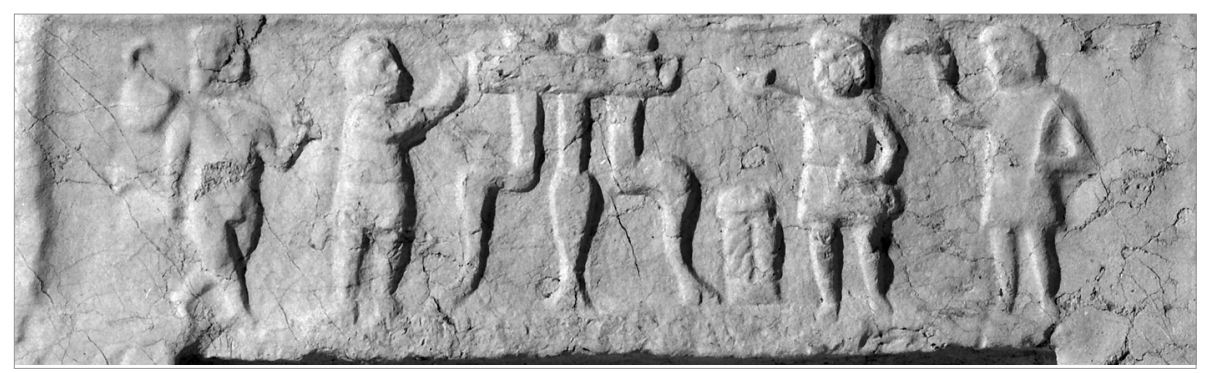

Slika 2: Pogrebna gostija na nagrobni steli Julije Jukunde (izrez), Narodni muzej Slovenije, inv. št. L I19, foto: Tomaž Lauko

V oči bode dejstvo, da izven črnomaljskih nagrobnikov v Neviodunu $\mathrm{z}$ agrom ni nobenih drugih upodobitev pogrebne gostije v kamnu, je pa stenska slika s tem prizorom krasila podzemno grobnico iz 2. stoletja na zahodni mestni nekropoli, v smeri proti Emoni. Poslikava se je žal ohranila le na risbi Hansa Pečnika, sina izkopavalca, starinokopa Jerneja Pečnika (Lovenjak 2008, 83, op. 36) iz osemdesetih let 19. stoletja (Šašel Kos 1997, 403; Kastelic 1998, 323-24, 435-37). Na njej je upodobitev zajeta povsem druga- 


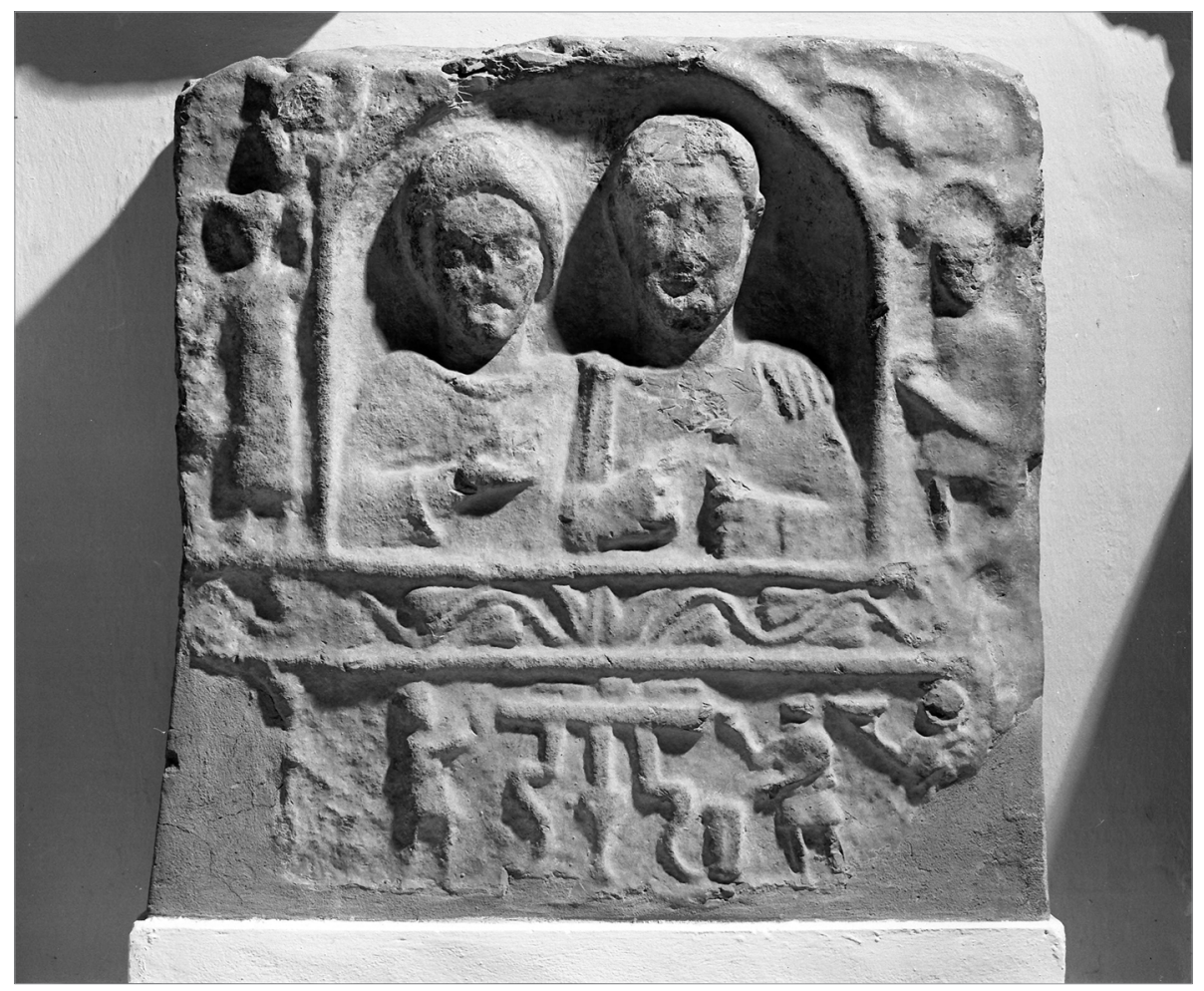

Slika 3: Nagrobna stela zakoncev, Narodni muzej Slovenije, inv. št. L 98, foto: Tomaž Lauko

če in obedovalci sedijo na polkrožnem ležišču (stibadium) ob trinožni mizi s posodo in kosi sadja na njej, streže pa jih služabnik na levi (Deschmann 1886, 24-27; Petru 1977, 26).

Iz Siscije je sicer znana le ena delno ohranjena upodobitev pogrebne gostije s stele Gaja Antonija Sentina (Sisak, Gradski muzej Sisak, inv. št. 22659; Migotti 2016, 175-76, št. 7; Migotti in Šašel Kos 2018, 8-9, št. 3; Lupa n. d., 30042). Prizor se nahaja nad epitafom, na levi je ob stebru služabnik, sledita vrč in trinožna miza s kantharosom, ki je pomaknjena nekoliko $\mathrm{v}$ desno. Za tem je slabo vidna še noga postelje (?), pod katero se skriva obredna posoda. Stela je datirana med leti 90 in 120 po Kr. in tako po strukturi kot ikonografiji odseva produkcijo Zgornje Germanije (Migotti 2016, 182, 188), s črnomaljskima stelama pa $\mathrm{z}$ izjemo generičnih značilnosti nima skupnega. 


\section{Satiru podoben lik na prizoru pogrebne gostije s stele Julije Jukunde}

Skrajno levi lik s pogrebne gostije na steli Julije Jukunde je za prizor pogrebne gostije na moč nenavaden in na drugih reliefih s tem prizorom ne nastopa, saj trinožno mizo obdajajo izključno služabniki. Njegova drža, upodobitev v koraku in pa tudi pastirska palica, ki jo drži v eni roki, so v prvi vrsti značilni za neka druga mitološka bitja, za satire. Ti so sicer relativno dobro zastopani na kamnitih nagrobnih spomenikih, zlasti na sarkofagih, še bolj kot v Panoniji pa so pogosti v sosednjem Noriku. Po klasifikaciji Friedricha Matza starejšega črnomaljski lik še najbolj ustreza tipu Askophoros A, pri katerem satir v enaki drži stopa proti desni in se obrača nazaj (Matz 1968, 46). Desno roko ima spuščeno, levo pa dvignjeno in z njo drži vinski meh, ki ga tovori na ramenih, medtem ko črnomaljski lik stiska pastirsko palico, na koncu katere je verjetno obešena košara. Nož za obrezovanje trte sicer spada med atribute satirov (npr. sarkofag v Rimu, Kapitolinski muzeji, inv. št. 1884), medtem ko je srp eden izmed običajnih atributov personifikacije Poletja (Kranz 1984, 124), pri čemer velja še omeniti, da je na drugi strani tudi nož za obrezovanje trte skupaj s pastirsko palico značilen npr. za Jesen (npr. Jesen na »triptihu« v Bad Waltersdorfu in »triptihu« v Hartbergu). ${ }^{2}$

$\mathrm{V}$ primerjavi s preostalim delom rimskega cesarstva je $\mathrm{v}$ Zgornji Panoniji in še toliko bolj $\mathrm{v}$ sosednjem Noriku relativno veliko upodobitev, na katerih so Letni časi enako kot črnomaljski lik upodobljeni v podobi genijev v koraku. Zaradi sorodne drže in $\mathrm{v}$ nekaterih primerih tudi enakih atributov (pastirska palica, nož za obrezovanje trte) kot pri satirih je ob pomanjkanju najdiščnih okoliščin oziroma preostalih delov nagrobnega spomenika, ki mu je reliefna upodobitev prvotno pripadala, nemalokrat celo težko presoditi, koga lik dejansko predstavlja (Pochmarski-Nagele 1992, 172).

Ne v Neviodunu in ne v Sisciji ni primerljivih likov, se jih pa nekaj nahaja na nagrobnih reliefih $\mathrm{v}$ provinci Norik. Po drži in košari oziroma culici na koncu pastirske palice tako ustrezajo satiri na nagrobni ari v Svetem Petru v Lesu/Sankt Peter in Holz (Pochmarski-Nagele 1992, 7475, št. 63; Lupa n. d., 2197), relief, vzidan v grad Seggau v bližini Lipnice/

2 Ne najustreznejši izraz »triptih« je za oba reliefa prvič uporabila E. Diez (1954), nanaša pa se na njuno tridelno zasnovo, ki spominja na oltarni triptih. Za Bad Waltersdorf: Pochmarski-Nagele 1992, 69, št. 57; Kremer 2001, 65, št. I 6d; Wagner 2001, 461; Pochmarski in Pochmarski-Nagele 2005, 149; Lupa n. d., 6069. Za Hartberg: Diez 1954; Pochmarski-Nagele 1992, 68-69, št. 56; Kremer 2001, 202, št. II 99; Wagner 2001, 462; Pochmarski in Pochmarski-Nagele 2005, 141-47. 


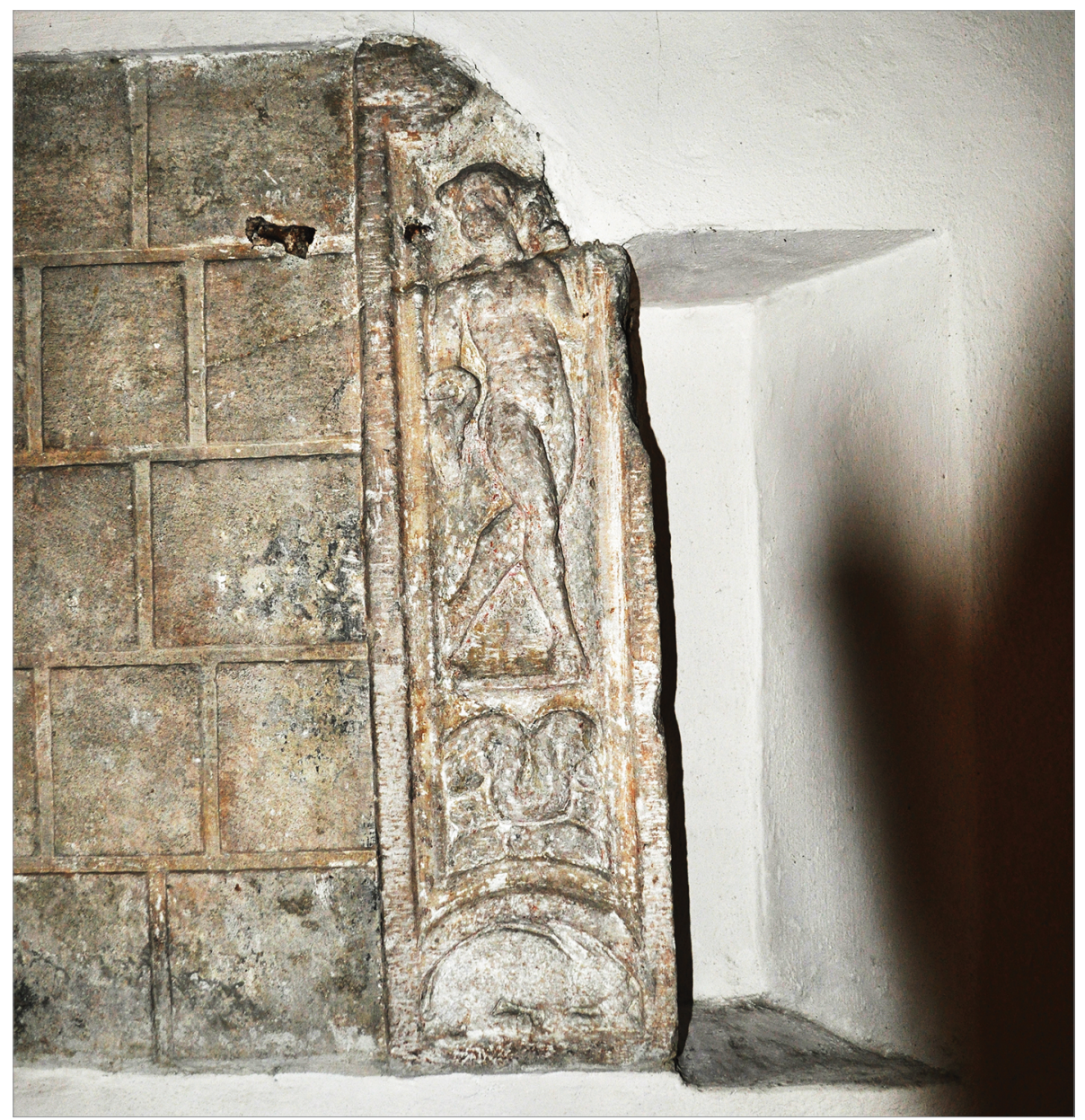

Slika 4: Satir, del grobne edikule, Šentvid na Glini, vzidane v notranjščino cerkve sv. Trojice pod pevskim korom

Leibnitz (Pochmarski-Nagele 1992, 75-76, št. 64; Lupa n. d., 1281), mladenič v Tiffnu na Koroškem (vzidan v župnijsko cerkev sv. Jakoba Starejšega; Pochmarski-Nagele 1992, 69-70, št. 58; Kastelic 1998, 398; Lupa n. d., 1036), in delno ohranjeni relief v Gradcu (Universalmuseum Joanneum, inv. št. 231; Pochmarski-Nagele 1992, 76, št. 65; Lupa n. d., 1153), pri katerem po analogijah lahko domnevamo, da je prav tako na koncu palice bingljala košara. Nihče izmed njih pa v roki ne nosi srpa oziroma podobno ukrivljenega predmeta. Srp kot atribut nosi edinole satir na desni strani dela edikulne grobnice v Šentvidu na Glini/Sankt Veit an der Glan (vzidana v notranjo- 
st župnijske cerkve sv. Trojice pod pevskim korom; Piccottini 1984, 34-35, št. 329-30; Pochmarski-Nagele 1992, 72-74, št. 61-62; Kremer 2001, 274-75, št. II 392; slika 4).

Vsi ti noriški reliefi naj bi zaradi ikonografskih lastnosti nastali po prvi četrtini 3. stoletja, pri čemer je datacija opredeljena z ozirom na njihovo pojavnost na sarkofagih Letnih časov produkcije mesta Rim (Kranz 1986, 208-11, 232-34; Pochmarski-Nagele 1992, 171).

\section{Zaključek}

V literaturi sta bili Julijina stela in njej najpodobnejša druga črnomaljska stela vselej postavljeni v enak časovni okvir, in sicer tako ob konec 1 . oziroma 2. stoletje (Lovenjak 1998, 305; 2008, 84, 93, št. 5, št. 13) kot še bistveno kasneje, ob konec 2. oziroma začetek 3. stoletja (Šašel Kos 1997, 403, št. 142). Epitaf je žal preslabo ohranjen, da bi prispeval k natančnejši časovni opredelitvi. K njej tako še najbolj prispevata individualizirana pričeska Julije Jukunde in zagoneten lik v prizoru s pogrebno gostijo. Upoštevaje pričesko pokojnice, ki z valovitimi kodri spominja na pričeske članic vladarske rodbine severske dinastije, morda še najbolj na frizuro Julije Majse (Ziegler 200o, 84, op. 59), se zdi verjetnejša kasnejša datacija. K slednji nagovarja tudi lik satira ali personifikacije Letnih časov na Julijini steli, saj se ne nazadnje prepletanje ikonografije letnih časov z bakhičnim svetom prvič zasledi na sarkofagih Letnih časov rimske produkcije šele $\mathrm{v}$ poznoantoninskem obdobju (Kranz 1984 173; 1986, 209), po prvi četrtini 3. stoletja pa naj bi nastale tudi sorodne figure sosednjega Norika.

V 3. stoletju so si nagrobni spomenik lahko pretežno privoščili pripadniki vsaj višjega srednjega sloja in vojaštva, s sagumom na sebi pa so se upodobili tudi civilisti, ki so se uvrščali med honestiores, torej pripadnike municipalne ali cesarske administracije, od katerih je marsikdo začel kariero v vojaških vrstah (Migotti 2013, 268). Kljub nedvomno večji priljubljenosti tega tipa oblačila $v 3$. stoletju pa velja opozoriti, da tudi poprej ni bil neznan pri civilnem prebivalstvu; za najstarejšo znano upodobitev saguma tako velja nagrobni spomenik Tiberija Julija Avita (Lupa n. d., 1465) iz zgodnjega 2. stoletja, marsikateri primerki pa segajo še $\mathrm{v}$ antoninsko dobo (Rothe 2012, 160-63; Hainzmann 2015, 267).

Glede na to, da ne v Sisciji in ne v Neviodunu prizor pogrebne gostije z ozirom na ohranjene primerke očitno ni bil običajen, je zanimivo, da so se upodobitve zgostile prav v tej regiji, kjer sicer produkcija $\mathrm{z}$ umetnostnega gledišča (po ohranjenem materialu sodeč) ni bila ravno prvovrstne kvali- 
tete (cf. Lovenjak 1998, 283), in po vsebini prej kaže povezave z balkanskim prostorom (Lovenjak 20o8, 95). Lahko bi šlo za neko ozko geografsko omejeno lokalno posebnost, ki bi jo tja zanesel kak potujoči kamnosek, ki se je s temi, sicer v rimski dobi pogostimi, upodobitvami seznanil v enem od panonskih žarišč te tematike, motiv pa so posnemali tudi drugi obrtniki. Upoštevaje drugačno zasnovo in bolj rustikalno izdelavo preostalih črnomaljskih nagrobnikov s tem prizorom se zdi namreč izdelava vseh v eni delavnici manj verjetna.

Vprašanje ostaja, čemu se je kamnosek na nagrobnem spomeniku Julije Jukunde odločil za upodobitev lika, ki nima nobene povezave s prizorom pogrebne gostije, prav tako ne Letnih časov ne satirov ne najdemo ne v Neviodunu ne v Sisciji, so pa na drugi strani pogosti zlasti v provinci Norik, kjer oboji često nastopajo na nagrobnih spomenikih. Še posebej v nemirnem 3. stoletju so eni in drugi utelešali hrepenenje po izobilju in blagostanju ter uživanju v življenju, na kar naj bi kazalo upodabljanje figur v veselem, plesnem koraku (Zanker in Ewald 2004, 135-36, 139). Možno je, da je lik kamnosek videl in situ ter ga preslikal na črnomaljski spomenik, s čimer je želel na njem (in verjetno še na ikonografsko sorodni steli) dodatno poudariti pokojnikovo heroizacijo ter upanje na srečno posmrtno življenje; iz istih razlogov pa bi si to podobo lahko zaželel tudi naročnik. Manj verjetno se zdi, da bi ga uporabil le kot »mašilo« za zapolnitev praznega prostora, saj bi se sicer - tudi zaradi boljše simetričnosti - verjetneje odločil za lik služabnika.

\section{Viri in Literatura}

\section{Literatura}

Barkóczi, L. 1982-1983. »Die südöstlichen und orientalischen Beziehungen der

Darstellungen auf den ostpannonischen Grabstelen." Mitteilungen des Archäologischen Instituts der Ungarischen Akademie der Wissenschaften 12-13: 123-51.

Burger, A. 1959. Áldozati jelenet Pannonia köemlékein / Die Opferszene auf pannonischen Steindenkmälern. Budimpešta: Magyar Nemzeti MúzeumTörténeti Múzeum Budapest.

Ciongradi, C. 2007. Grabmonument und sozialer Status in Oberdakien. ClujNapoca: Mega Verlag. 
Conrad, S. 2004. Die Grabstelen aus Moesia Inferior: Untersuchungen zu Chronologie, Typologie und Ikonografie. Leipzig: Casa Libri.

Deschmann, K. 1886. „Die neuesten römischen Funde von Dernovo (Neviodunum) in Unterkrain." Mittheilungen der K.K. CentralCommission zur Erforschung und Erhaltung der Kunst- und Historischen Denkmale 12: 17-36.

Diez, E. 1954. »Ein bakchisches Tryptichon."Jahreshefte des Österreichischen Archäologischen Instituts 41: 90-96.

Diez, E. 1959-1961. „Zur Darstellung des Totenopfers auf norischen Grabsteinen.« Schild von Steier 9: 47-57.

Diez E. (1960) 2011. "Parallelen und Differenzen in der norischen und pannonischen Kunst."V Unveröffentlichte archäologische Vorträge aus vier Jahrzehnten, ur. B. Hebert in G. Schwarz, 65-82. Dunaj; Berlin: Lit Verlag.

Dunbabin, K. 2003. The Roman Banquet: Images of Conviviality. Cambridge: Cambridge University Press.

Hainzmann, M. 2015. „SAGUM: Zu problematischen Datierungsansätzen eines keltisch-römischen Kleidungsstückes."V Cult and Votive Monuments in the Roman Provinces: Proceedings of the 13th International Colloquium on Roman Provinical Art, ur. C.-G. Alexandrescu, 263-74. Cluj-Napoca: Mega Publishing House.

Handy, M., in E. Pochmarski. 2016. „Ein bakchisches Tryptichon.« Jahreshefte des Österreichischen Archäologischen Instituts 41: 90-96: 107-30.

Hoffiller, V., in B. Saria. 1938. Antike Inschriften aus Jugoslavien: Noricum und Panonia Superior. Zagreb.

Kastelic, J. 1998. Simbolika mitov na rimskih nagrobnih spomenikih: Šempeter v Savinjski dolini. Ljubljana: Slovenska matica.

Kranz, P. 1984. Jahreszeiten-Sarkophage: Entwicklung und Ikonographie des Motivs der vier Jahreszeiten auf kaiserzeitlichen Sarkophagen und Sarkophagdeckeln. Berlin: Mann.

Kranz, P. 1986. »Die Grabmonumente von Šempeter: Beobachtungen zur Entwicklung der Bildhauerkunst in Noricum während der mittleren und späten römischen Kaiserzeit.« Bonner Jahrbücher 186: 193-239.

Kremer, G. 2001. Antike Grabbauten in Noricum: Katalog und Auswertung von Werkstücken als Beitrag zur Rekonstruktion und Typologie. Dunaj: Österreisches Archäologisches Institut.

Lovenjak, M. 1998. Neviodunum. Ljubljana: Narodni muzej Slovenije. 
Lovenjak, M. 2008. »Rimski nagrobniki iz Črnomlja.« V Črnomaljski zbornik: zbornik historičnih razprav ob 780 -letnici prve omembe naselja in 6oo-letnici prve omembe Črnomlja kot mesta, ur. J. Weiss, 75-97. Črnomelj: Občina Črnomelj.

Matz, F. 1968. Die dionysischen Sarkophage 1: 1. Die Typen der Figuren. Die Denkmäler 1-71 B. Berlin: Mann.

Migotti, B. 2013. „Can Soldiers on 3rd-Century Stelae in Panonnia be Recognized only by the Sagum?« V Rimska vojna oprema u pogrebnom kontekstu: Radovi XVII. ROMEC-a/Weapons and Military Equipment in a Funerary Context: Proceedings of the XVIIth Roman Military Equipment Conference/Militaria als Grabbeilage: Akten der 17. Roman Military Equipment Conference, ur. M. Sanader idr., 259-71. Zagreb: Filozofski fakultet - Arheološki muzej.

Migotti, B. 2016. "The Military Stelae of Northern Croatia."V The Roman Army between the Alps and the Adriatic, ur. J. Horvat, 171-91. Ljubljana: Založba ZRC.

Migotti, B. 2018. »Territories of Andautonia, Aquae Balissae and Siscia.« V Roman Funerary Monuments of South-Western Pannonia in their Material, Social, and Religious Context, ur. B. Migotti, M. Šašel Kos in I. Radman-Livaja, 133-42. Summertown, Oxford: Archaeopress Publishing Ltd.

Migotti, B., in M. Šašel Kos. 2018. »Catalogues. "V Roman Funerary Monuments of South-Western Pannonia in their Material, Social, and Religious Context, ur. B. Migotti, M. Šašel Kos in I. Radman-Livaja, 5-132. Summertown, Oxford: Archaeopress Publishing Ltd.

Noelke, P. 200o. "Zur Chronologie der Grabreliefs mit Mahldarstellung im römischen Germanien." V La sculpture d'époque romaine dans le Nord, dans l'Est des Gaules et dans les régions avoisinantes: Acquis et problématiques actuelles, ur. H. Walter, 59-70. Pariz: Presses Universitaires Franc-Comtoises.

Noelke, P. 2005. "Zu den Grabreliefs mit Darstellung des convivium coniugale im römischen Germanien und im benachbarten Gallien.« Bonner Jahrbücher 205: 155-241.

Petru, P. 1977. Neviodunum - Drnovo pri Krškem. Maribor: Obzorja.

Piccottini, G. 1984. Die kultischen und mythologischen Reliefs des Stadtgebietes von Virunum. Dunaj: Österreichische Akademie der Wissenschaften.

Pochmarski, E. 1996. „Severische Reliefs aus dem Stadtterritorium von Virunum.« V Akten des 3. Internationalen Kolloquiums über Probleme 
des provinzialrömischen Kunstschaffens, ur. G. Bauchhenß, 127-39. Köln: Rheinland-Verlag.

Pochmarski, E., in M. Pochmarski-Nagele. 2005. „Die dionysischen Dreifigurenreliefs von Hartberg und Bad Waltersdorf (Steiermark).« $\mathrm{V}$ Religija i mit kao poticaj rimskoj provincijalnoj plastici: Akti VIII. Međunarodnog kolokvija o problemima rimskog provincijalnog umjetničkog stvaralaštva/Religion und Mythos als Anregung für die provinzialrömische Plastik: Akten des VIII. Internationalen Kolloquiums über Probleme des provinzialrömischen Kunstschaffens/Religion and Myth as an Impetus for the Roman Provincial Sculpture: The Proceedings of the 8th International Colloquium on Problems of Roman Provincial Art, ur. M. Sanader in A. Rendić Miočević, 141-55. Zagreb: Tehnička knjiga.

Pochmarski-Nagele, M. 1992. Die dionysischen Reliefs in Noricum und ihre Vorbilder. Dunaj: VWGÖ.

Rothe, U. 2012. "Clothing in the Middle Danube Provinces: The Garments, Their Origins and Their Distribution."Jahreshefte des Österreichischen Archäologischen Institutes in Wien 81: 137-231.

Saria, B. 1933. "Novi napisi iz Kranjske.« Glasnik muzejskega društva za Slovenijo 14 (1-4): 5-27.

Schober, A. 1923. Die römischen Grabsteine von Noricum und Pannonien. Dunaj: Hölzel.

Stewart, P. 2009. »Totenmahl Reliefs in the Northern Provinces: A Case-Study in Imperial Sculpture. " Journal of Roman Archaeology 22 (1): 253-74.

Šašel, J. 1985. »K rimskim napisom v Beli Krajini.« Arheološki vestnik 36: 325-36.

Šašel Kos, M. 1997. The Roman Inscriptions in the National Museum of Slovenia. Ljubljana: Narodni muzej Slovenije.

Ubl, H. 2013. Waffen und Uniform des römischen Heeres der Prinzipiatsepoche nach den Grabreliefs Noricums und Pannoniens. Dunaj: UniPress.

Wagner, J. 2001. »Zur ostentativen Wiederverwendung römerzeitlicher Spolien in mittelalterlichen und frühneuzeitlichen Kirchenbauten der Steiermark: Bannung, Exorzismus und humanistische Intentionen im Spiegel einer Interpretatio christiana." Fundberichte aus Österreich 40: 345-479.

Zanker, P., in B. C. Ewald. 2004. Mit Mythen leben: Die Bilderwelt der römischen Sarkophage. München: Hirmer.

Ziegler, D. 2000. Frauenfrisuren der römischen Antike: Abbild und Realität. Berlin: Weißensee Verlag. 


\section{Spletni vir}

Lupa. N. d. Die Bilddatenbank Ubi Erat Lupa. http://lupa.at/.

\section{Summary}

\section{The Funerary Banquet in the Grave Stele of one Iulia Iucunda from Črnomelj}

The article discusses the grave stele of one Iulia Iucunda, found in Črnomelj in the province of Pannonia (National Museum of Slovenia, inv. no. L 119). The busts of the couple are carved within the main field, whereas the relief frieze bearing the scene of the funerary banquet (cena funebris, German Totenmahl) follows below. It is represented in differentia specifica for that province, as the reclining deceased is absent.

The unexpected figure for the funerary banquet is the naked figure at the far left, stepping towards mensa tripes. Considering its posture, it resembles the satyrs (type Askophoros A) or the personifications of the Seasons as the youth. In their left, the figure carries a pedum, with a basket or a bundle (?) hanging down from its bent end. In their other hand, a hardly distinguishable curved object is visible: a sickle or a pruning knife (?). However, the pedum is the standard attribute for both mythological entities, while the sickle is common for the personification of Summer, and the pruning knife for both, satyrs, and Autumn. As both mythological beings share the posture as well as several attributes and the carved figure is mal preserved, it is almost impossible to claim which one of them is shown. However, none of them is represented in the funerary sculpture neither in Neviodunum nor in Siscia, although both are quite popular in the adjacent province of Noricum, in which the comparable figures are dated after the first quarter of the $3^{\text {rd }}$ century.

One of the open issues is the dating of the stele, as in the hitherto literature it spans from the late 1st till the beginning of the $3^{\text {rd }}$ century. As the coiffure of the spouse resembles the Severan hair dresses, perhaps mostly the one of Iulia Maesa, and her husband wears a sagum, which was worn by both, military and civilians, especially after the rule of emperor Caracalla, the dating to the first third of the 3 rd century seems more plausible. 